\title{
急激な塩分変化がマダイの血液性状におよ活す影響和
}

\author{
石: 岡宏子 \\ $(1980$ 年 8 月 11 日受理)
}

\section{Stress Reactions Induced by Environmetal Salinity Changes in Red Sea Bream}

\author{
Hiroko IsHIOKA*2
}

Stress reactions in marine fish were studied in determining the effects of environmental salinity changes on the haematology of the red sea bream, Chrysophrys major TEMMINCK et SCHLEGEL.

Acute elevation in environmental salinity induced hyperglycemia, increase of serum sodium, chloride and cortisol levels of the fish. The fish exposed to acute salinity lowering showed hyperglycemia, increase of serum cortisol level and high haematocrit values with low sodium and chloride levels. It was confirmed that these haematological changes depended on the intensity and the rate of salinity change.

The determination of the phases in stress reactions was examined through the use of Euclidean distances calculated by 3 variables; mean haematocrit value, mean glucose level and mean serum sodium level. They were recognized to include control phase, reactive phase where the hyperglycemia was noticeable and exhausitive phase where serum sodium level was remarkably influenced by environmental salinity. These phases were considered to be slightly affected by stimuli-specific reactions of the fish.

魚が飼育環境の塩分变化にどのように適応しているか は, 昔から重要な研究課題の1つであつた。鰓, 腎, 消 化管等の形態, 機能变化 $\left.{ }^{1 \sim 3}\right)$, イオンの能動輸送攵, 8 , 内

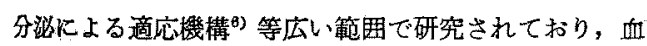

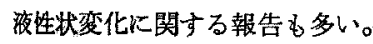

マダイは、日本沿岸海域に広く棲息し，古くから，塩 分耐性の強い魚であるとして知ら机ているが，意外任生 理学的観点からの研究は少ない。 ここでは，前報にひきつづき環境要因の一つである塩 分変化をストレッサーとして与え，マダイの血液性状に 現われる变化の特徵を把握し，そのストレス状態につい て解析を行つた。

\section{材料およひ実験方法}

供試、ダイは，一年魚を用い，材料の䆏入や保存飼青 中生物実験系は，原則として前報》と同様であつた。塩 分上㫧刺激を流水系で設定することは困難であつたの

で, 止水系之し，直接，粗製塩化ナトリウムを，拡汼を 目的とし，エフストーンの上部位置より投入した。塩分 低下刺激は,ストレッサー調整水槽次水道水を導入する
ことによつて達成したが，急激な条件变化設定の場合に は, 水道水を直接実験水槽に導入した。実験条件の詳細 を, Table 1 亿示す。塩分変化の状況は, 前もつて水 槽内に設固したサイフォン管上り経時的に採水し，通常 の塩検に上り求めた。一方, 実験水槽内には, サリノメ ーター (オートラボ, ポーターブル S-T 計 602 型)を 沈めて扣き，塩分の变化状沅をモニターした。

实験魚は静か汇採り上げ麻酔せず们直接キュビエ氏管 上り2本の注射器で採血した。1本はへパリン酸ンーダ を加えて和り，へモグロビン，へマトクリット等の測定

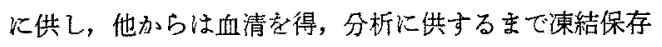
した。

$$
\text { ヘモグロビンは人モみーター（米国 A.O. 社製)によ }
$$

り, ヘマトクリットはミクロへマトタリット法により,

蛋白質はミクロビューレット法により、グルコースは醇 素法, クロライドは, シャールス・シャールス変法によ り，それぞれ，SPINCOの超溦量分析装置を用いて分 析した。ナトリウム,カリウム, マグネシウム, カルシ ウムは原子吸光分析により、ニーチゾールは, RIA 法 または CPBA 法による分析童行つた。

*1 南西海区水産研究所業縝第 100 号。海産魚のストレス反応に関する研究一II (Stress Roactions in the Marine Fish-II).

*2 南西海区水應研究所 (Nansei Regional Fisheries Research Laboratory, Maruishi, Ohno, Saiki-gun, Hiroshima 739-04, Japan). 
Table 1. A list of the experimental conditions in the study on stress reactions of the red sea bream under the changes of environmenal salinity

\begin{tabular}{|c|c|c|c|c|c|c|}
\hline Experiment number & 1 & II & III & $\mathrm{IV}$ & $\mathrm{V}$ & $\mathrm{VI}$ \\
\hline Time of experiment & Oct. 1976 & May 1978 & July 1976 & June 1978 & Oct. 1976 & July 1975 \\
\hline No. of the fish & 10 & 40 & 28 & 40 & 10 & 30 \\
\hline Body length $(\mathrm{cm})^{*}$ & $16.3 \pm 0.70$ & $12.0 \pm 0.17$ & $14.6 \pm 1.19$ & $12.6 \pm 1.09$ & $16.6 \pm 1.06$ & $14.5 \pm 0.54$ \\
\hline Body weight $(\mathrm{g})^{*}$ & $157.3 \pm 20.83$ & $54.5+110.82$ & $108.4 \pm 23.49$ & $64.2 \pm 16.13$ & $166.0 \pm 28.10$ & $100.0 \pm 20.90$ \\
\hline State of water & Still & Running & Running & Running & Running & Still \\
\hline Acclimation period in the & & & & & & \\
\hline$\underset{\text { (days) }}{\text { experimental system }}$ & 4 & 7 & 30 & 10 & 14 & 0 \\
\hline Temperature $\left({ }^{\circ} \mathrm{C}\right)$ & 22 & $15.5-16.5$ & $20.0-23.5$ & $17.8-19.8$ & 22.5 & 25.0 \\
\hline Acclimation chlorinity $(\%)$ & 16.5 & 17.5 & 16.5 & 17.8 & 16.5 & - \\
\hline Attained chlorinity $(\%)$ & 33.5 & 39.8 & 5.06 & 5.6 & 0.9 & 3.33 \\
\hline
\end{tabular}

* mean \pm S.D.

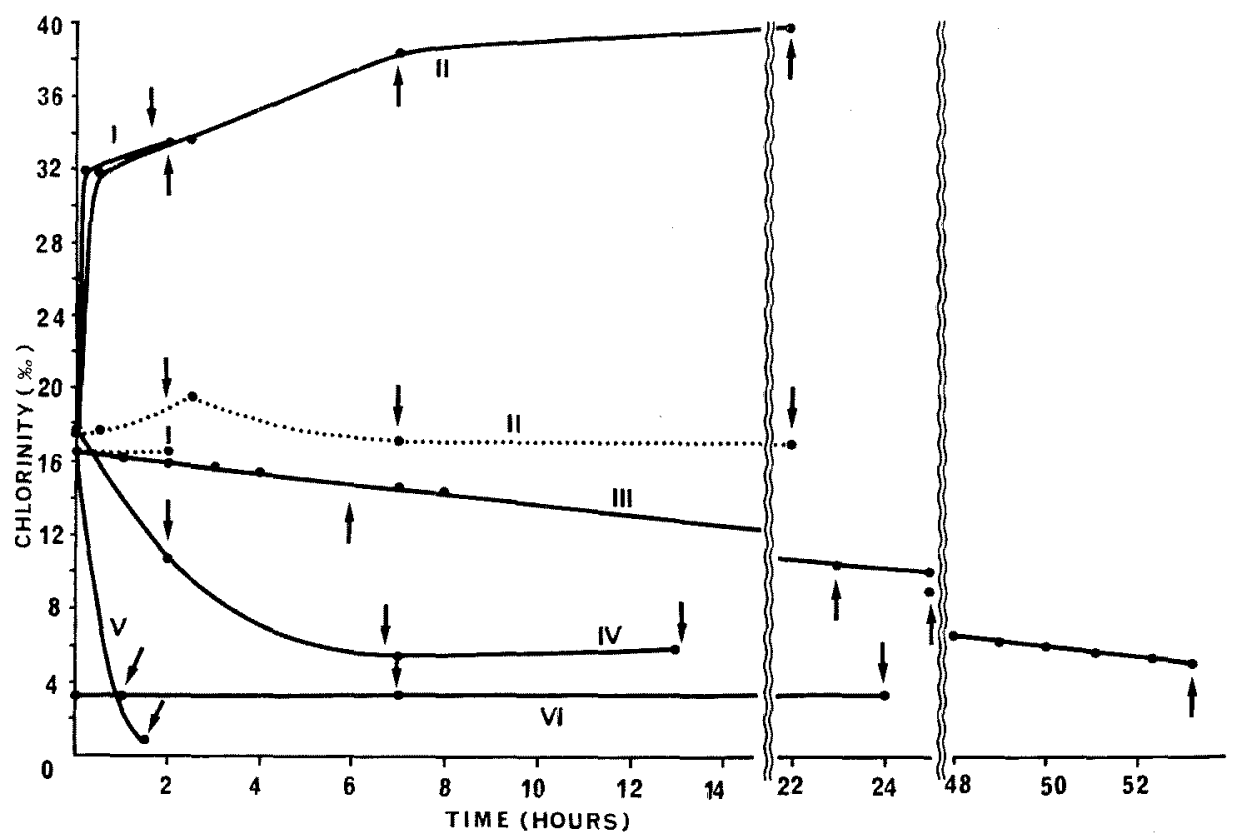

Fig. 1. Changes of environmental chlorinity in the experiments on the stress reactions of the red sea bream. The experimental numbers are the same as in Table 1. Arrows: sampling time, ...... controls in experiment I and II.

\section{結果}

塩分变化の状況を，Fig. I に示す。车驗 I，II の場 合の対照区の塩分変化例をむ図中に併記したが他法省略 した。これは，実䮖 II場台に実験区水が一部混入して 塩分上界が考えられたためである。他の実験で期間中

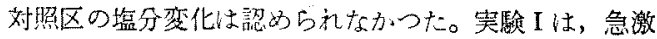
な塩分上㫧変化が与无ら机た時のごく初期の反応を知る ための垁験として設定した。この範柬時間内ては，行動 異常魚, 整死魚は認めら机なからた。
実験 IIは，同程度の条件で 22 時間後まで経過を観察 した。ここでは，10 時間以後 20 時間までの間に 4 尾が 慗死した。

実驗而では，塩分低下は極めてゆるやか心行和れ，行 動異常魚も，檠死魚も全く認められなからた。

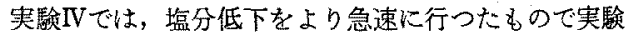
開始後 30 分で，水槽上層部を急速に遊泳する行動異常 魚が 3 尾認められ，約 5 時間後には体色は黑つぽく，底 層で動かない個体が数尾観察された。9.5 時間後には横 転魚が認められ，10 時間後には 1 尾が整死した。13 時 
間後には；残存魚全部をとり上げた。

実驗Vでは，さらに急激な塩分低下の場合の初期の反 応をとらえよらとしたものであり，特に行動異常魚中擎 㽝魚は認められなかつた。しかし，採集した血夜の溶血 は著しく，分析値も容血の影響を大きくらけていると考 学られた。

実歌りは，極端に桸釈された飼育水中に固いた魚の状 態を知るために設定したもので，順応海水から急激に稀 秎水中に䔟した。1 時間後には，やや遊泳が早い程度で あつたが，7時間後には整死魚が出はじめ, 明らかな異 常遊泳魚が認められた。24 時間後にからうじて生残し た個体 3 尾は横転して㧊り，眼球は，水晶体中心部を除 いて白濁していた。

これらから実験皿以外注, 塩分の変化速度と絶対値等 はマダイにとつて致死的な条件であると判断された。

血夜性状変化を Tables 2, 3, Figs. 2 4 に示守。

ヘモゲロビン量：塩分上昇時には実験Ｉと【で異なる 結果を得た。鮇体の大きさ，対照区の值の差暴がある し，また塩分变化の与え方や実験時期が異なるので, 厳 密な比較は出来ない。塩分低下時には, 全実龭を通して 変動はほ上んど認められず，実験IVのみで，対象区より 有意な上昇が認められただけである。へモグロビン量 は, 各赛歌とも個体差が大きく, 今回の実験からでは, 一定の㑯向を得ることが出来なかつた。

ヘマトクリット值：Fig. 2 に示しょたらに，塩分上 昇時 (I， II) 飞注，一時的な增加と減少が認められた。 塩分低下時には，実棌而を除いて，すべて一時的な上昇 が認められている。すなわち，実験皿のよらにゆるやか な塩分低下時には，一マトクリット值は，わずかと低下
時期はあるものの，ほとんど変動がない状態であるが， 実験IV,V，VIのように急激な塩分変化時には, へマト クリット值の有意な上昇が認められている。

蛋白罂量：塩分上升時に実駰 I で蛋白質量減少が認

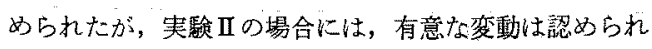
なからた。塩分低下刺激を与充た場合には，蛋白質量は 実騟每に大きく異なつているにもかかわらず，同一の傾

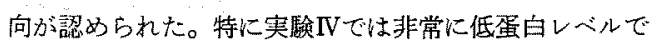

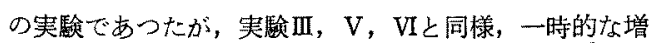
加傾向が認められた。夷虽 $\mathrm{V} の 14.2 \mathrm{~g} / 100 \mathrm{~m} l$ という值 は, 明らかに翼常であり, 溶血の影響と考充られだ。

グルコース量：塩分上昇と下降封にいずれもグルュー ス上昇があるようである (Fig. 3)。実験I の場合の時間 笧围では上昇は認められていないが，実験IIでは 2 時間

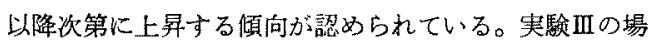
合は塩分低下速度が大きくなく，個体差も大きいので， 有意な上昇注認められていない。実驗 V の時間範田で は，上昇は認められていない。実驗Vでは 1 時間後の有 意な上昇の後，7時間目に有意のグルコース低下を示し ている。

クロライド量：この成分は，予想されたよらに塩分上 昇時には上昇の㑯向を示す。しかし急激な塩分上昇の場 合でも最初はあまり高い值を示ざす，整死魚が出る状態

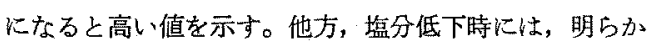
にクロライド量は減少の㑯向を示す。これは, 実験条件 儿対応しており，塩分低下速度が急激な場合（実験 $\mathrm{V}$, VI）には，血中クロライドは低下するが，速度がゆるや かな場合（実験III，IV)には，低下も軽度である。

ナトリウム量：クロライド量と同様, 塩分上昇時に

Table 2. Variations of haematological characteristics in red sea bream under the increase of environmental chlorinity

\begin{tabular}{|c|c|c|c|c|c|c|c|c|}
\hline$\underset{\text { (h) }}{\text { Time }}$ & $\begin{array}{l}\text { Haemoglobin } \\
(\mathrm{g} / 100 \mathrm{~m} l)\end{array}$ & $\begin{array}{c}\text { Protein } \\
(\mathrm{g} / 100 \mathrm{~m} l)\end{array}$ & $\begin{array}{c}\text { Chloride } \\
\text { (mEq) }\end{array}$ & $\begin{array}{l}\text { Potassium } \\
\quad(m E q)\end{array}$ & $\underset{(\mathrm{mEq})}{\text { Magnesium }}$ & $\underset{(\mathrm{mEq})}{\text { Calcium }}$ & $\begin{array}{c}\text { Cortisol } \\
(\mathrm{ng} / \mathrm{m} l)\end{array}$ & $\begin{array}{l}\text { Cluster } \\
\text { number }\end{array}$ \\
\hline \multicolumn{9}{|l|}{ Experiment I } \\
\hline $\begin{array}{c}0 \\
\text { (Control) }\end{array}$ & $\begin{array}{c}8.5 \pm 0.45 \\
(6)\end{array}$ & $\underset{\text { (6) }}{5.32 \pm 0.17}$ & $161.1 \pm \frac{4.62}{(6)}$ & $\begin{array}{c}5.01 \pm 0.62 \\
(6)\end{array}$ & $\begin{array}{c}2.05 \pm 0.10 \\
(5)\end{array}$ & $\begin{array}{c}8.97 \pm 0.11 \\
(5)\end{array}$ & $\begin{array}{l}24.6 \pm 10.38 \\
\text { (2) }\end{array}$ & \\
\hline 1.5 & $\begin{array}{c}6.9 \pm 0.32 * \\
\text { (4) }\end{array}$ & $\begin{array}{c}3.71 \pm 0.13^{*} \\
\text { (4) }\end{array}$ & $\begin{array}{c}179.0 \pm 1.18^{*} \\
\text { (4) }\end{array}$ & $\begin{array}{c}4.02 \pm 0.28 \\
\text { (4) }\end{array}$ & $\begin{array}{c}2.09 \pm 0.03 \\
\text { (4) }\end{array}$ & $\begin{array}{c}7.61 \pm 0.13^{\prime} \\
\text { (4) }\end{array}$ & $\begin{array}{l}142.5 \\
\text { (1) }\end{array}$ & 1 \\
\hline \multicolumn{9}{|l|}{ Experiment II } \\
\hline & $\begin{array}{c}5.2 \pm 0.27 \\
\text { (9) }\end{array}$ & $\begin{array}{c}2.23 \pm 0.06 \\
(8)\end{array}$ & $\begin{array}{c}166.1 \pm 2.41 \\
(8)\end{array}$ & $\begin{array}{c}7.53 \pm 0.75 \\
(10)\end{array}$ & $\begin{array}{c}1.48 \pm 0.01 \\
(5)\end{array}$ & $\begin{array}{c}5.84 \pm 0.03 \\
(5)\end{array}$ & $\begin{array}{c}99.9 \pm 42.56 \\
(5)\end{array}$ & \\
\hline 2 & $\begin{array}{c}6.0 \pm 0.27^{*} \\
(10)\end{array}$ & $\begin{array}{c}2.30 \pm 0.05 \\
(10)\end{array}$ & $\begin{array}{c}182.7 \pm 8.35 \\
(10)\end{array}$ & $\begin{array}{c}8.15 \pm 0.87 \\
(8)\end{array}$ & $\begin{array}{c}1.54 \pm 0.06 \\
(7)\end{array}$ & $6.15 \pm 0.15$ & $\begin{array}{c}7.6 \pm 4.97 \\
(5)\end{array}$ & 2 \\
\hline 7 & $\begin{array}{c}4.8 \pm 0.31 \\
(10)\end{array}$ & $\begin{array}{c}2.08 \pm 0.07 \\
\text { (9) }\end{array}$ & $\begin{array}{c}184.7 \pm 3.18^{*} \\
(9)\end{array}$ & $\begin{array}{c}5.12 \pm 0.50^{*} \\
(8)\end{array}$ & $\begin{array}{c}1.87 \pm 0.15 \\
(8)\end{array}$ & $\begin{array}{c}6.12 \pm 0.33 \\
(8)\end{array}$ & $\begin{array}{c}171.5 \pm 20.28 \\
(5)\end{array}$ & 3 \\
\hline 24 & $\begin{array}{c}6.2 \pm 0.59 \\
(6)\end{array}$ & $\begin{array}{c}2.14 \pm 0.09 \\
(5)\end{array}$ & $\begin{array}{c}233.7 \pm 4.54^{*} \\
(5)\end{array}$ & $\begin{array}{c}9.29 \pm 1.43 \\
(6)\end{array}$ & $\begin{array}{c}3.28 \pm 0.40^{*} \\
(3)\end{array}$ & $\begin{array}{c}5.97 \pm 0.13 \\
(3)\end{array}$ & $\begin{array}{c}444.5 \pm 17.53 * \\
\text { (3) }\end{array}$ & 4 \\
\hline
\end{tabular}

* Numbers and symbols are the same as in Fig. 2. 
Table 3. Variations of haematological characteristics in red sea bream under the decrease of environmental chlorinity

\begin{tabular}{|c|c|c|c|c|c|c|c|c|}
\hline$\underset{\text { (h) }}{\text { Time }}$ & $\begin{array}{l}\text { Haemoglobin } \\
(\mathrm{g} / 100 \mathrm{~m} l)\end{array}$ & $\begin{array}{l}\text { Protein } \\
(\mathrm{g} / 100 \mathrm{~m} l)\end{array}$ & $\begin{array}{c}\text { Chloride } \\
(\mathrm{mEq})\end{array}$ & $\begin{array}{l}\text { Potassium } \\
\quad(\mathrm{mEq})\end{array}$ & $\underset{(\mathrm{mEq})}{\text { Magnesium }}$ & $\underset{(\mathrm{mEq})}{\text { Calcium }}$ & $\begin{array}{l}\text { Cortisol } \\
\text { (ng/ml) }\end{array}$ & $\begin{array}{l}\text { Cluster } \\
\text { number }\end{array}$ \\
\hline \multicolumn{9}{|c|}{ Experiment III } \\
\hline $\begin{array}{c}0 \\
\text { (Control) }\end{array}$ & $\begin{array}{c}8.1 \pm 0.25 \\
(7)\end{array}$ & $\begin{array}{c}4.36 \pm 0.19 \\
(7)\end{array}$ & $\begin{array}{c}168.3 \pm 2.46 \\
(7)\end{array}$ & $\begin{array}{c}5.33 \pm 0.85 \\
(7)\end{array}$ & $\begin{array}{c}1.63 \pm 0.10 \\
(6)\end{array}$ & $\begin{array}{c}8.20 \pm 0.16 \\
(6)\end{array}$ & $\begin{array}{r}76.5^{\prime \prime} \\
(1)\end{array}$ & \\
\hline 6 & $\begin{array}{c}7.7 \pm 0.17 \\
(5)\end{array}$ & $\begin{array}{c}4.16 \pm 0.17 \\
(5)\end{array}$ & $\begin{array}{c}167.2 \pm 2.93 \\
(5)\end{array}$ & $\begin{array}{c}3.60 \pm 0.45 \\
(5)\end{array}$ & $\begin{array}{c}1.80 \pm 0.08 \\
(5)\end{array}$ & $\begin{array}{c}8.47 \pm 0.34 \\
(5)\end{array}$ & $\begin{array}{r}39.0^{\prime \prime} \\
(1)\end{array}$ & 5 \\
\hline 23 & $\begin{array}{c}8.9 \pm 0.67 \\
\text { (4) }\end{array}$ & $\begin{array}{c}5.15 \pm 0.26^{*} \\
(5)\end{array}$ & $\begin{array}{c}161.4 \pm 2.38 \\
(5)\end{array}$ & $\begin{array}{c}4.82 \pm 0.57 \\
(5)\end{array}$ & $\begin{array}{c}1.81 \pm 0.02 \\
(5)\end{array}$ & $\begin{array}{c}8.44 \pm 0.36 \\
(5)\end{array}$ & $\begin{array}{r}61.0^{\prime \prime} \\
(1)\end{array}$ & 6 \\
\hline 30 & $\begin{array}{c}7.9 \pm 0.34 \\
(4)\end{array}$ & $\begin{array}{c}4.10 \pm 0.14 \\
(5)\end{array}$ & $\begin{array}{c}171.5 \pm 1.03 \\
\text { (3) }\end{array}$ & $5.41 \pm 0.55$ & $\begin{array}{c}1.76 \pm 0.15 \\
(3)\end{array}$ & $8.97 \pm 0.09 *$ & - & 7 \\
\hline 53.3 & $\begin{array}{c}8.3 \pm 0.47 \\
(4) \\
\end{array}$ & $\begin{array}{c}4.89 \pm 0.24 \\
(5)\end{array}$ & $\begin{array}{c}142.5 \pm 3.29^{\prime} \\
(5) \\
\end{array}$ & $\begin{array}{c}4.97 \pm 1.03 \\
(4) \\
\end{array}$ & $\begin{array}{c}1.76 \pm 0.11 \\
(3) \\
\end{array}$ & $\begin{array}{c}9.03 \pm 0.32 * \\
(3) \\
\end{array}$ & $\begin{array}{r}32.0^{\prime \prime} \\
(1) \\
\end{array}$ & 8 \\
\hline \multicolumn{9}{|c|}{ Experiment IV } \\
\hline $\begin{array}{c}0 \\
\text { (Control) }\end{array}$ & $\begin{array}{c}6.0 \pm 0.45 \\
\text { (11) }\end{array}$ & $\begin{array}{c}2.46 \pm 0.08 \\
(10)\end{array}$ & $\begin{array}{c}164.5 \pm 2.07 \\
(12)\end{array}$ & $\begin{array}{c}6.38 \pm 0.66 \\
(11)\end{array}$ & $\begin{array}{c}1.49 \pm 0.03 \\
(7)\end{array}$ & $\begin{array}{c}5.88 \pm 0.12 \\
(7)\end{array}$ & $\begin{array}{c}6.5 \pm 2.69 \\
(6)\end{array}$ & \\
\hline 2 & $\begin{array}{c}6.9 \pm 0.33 \\
(9)\end{array}$ & $\begin{array}{c}2.82 \pm 0.14^{*} \\
(8)\end{array}$ & $\begin{array}{c}154.1 \pm 3.90^{\prime} \\
(9)\end{array}$ & $\begin{array}{c}8.37 \pm 0.47^{*} \\
(8)\end{array}$ & * $1.56 \pm 0.04$ & $\begin{array}{c}5.79 \pm 0.26 \\
(4)\end{array}$ & $\begin{array}{c}223.9 \pm 94.72 * \\
(5)\end{array}$ & 9 \\
\hline 7 & $\begin{array}{c}6.9 \pm 0.40 \\
(8)\end{array}$ & $\begin{array}{c}3.11 \pm 0.14^{*} \\
(5)\end{array}$ & $\begin{array}{c}147.5 \pm 5.85^{\prime} \\
(8)\end{array}$ & $\begin{array}{c}9.80 \pm 0.36^{*} \\
\text { (4) }\end{array}$ & $* 3.22 \pm 0.43 *$ & $\begin{array}{c}5.99 \pm 0.19 \\
(2)\end{array}$ & $\begin{array}{c}196.6 \pm 55.70^{*} \\
(5)\end{array}$ & 10 \\
\hline 13.3 & $\begin{array}{c}7.2 \pm 0.30^{*} \\
(9)\end{array}$ & $\begin{array}{c}3.90 \pm 0.41^{*} \\
(5)\end{array}$ & $\begin{array}{c}136.2 \pm 10.29^{\prime} \\
(9)\end{array}$ & $\begin{array}{c}8.67 \pm 0.36 * \\
(5)\end{array}$ & $\begin{array}{c}7.87 \pm 0.83^{*} \\
(2) \\
\end{array}$ & $\begin{array}{c}7.98 \pm 0.69 * \\
(2)\end{array}$ & $\begin{array}{c}245.5 \pm 160.57 \\
(4)\end{array}$ & 11 \\
\hline \multicolumn{9}{|c|}{ Experiment $\mathrm{V}$} \\
\hline $\begin{array}{c}0 \\
\text { (Control) }\end{array}$ & $\begin{array}{c}8.5 \pm 0.45 \\
(6)\end{array}$ & $\begin{array}{c}5.32 \pm 0.17 \\
(6)\end{array}$ & $\begin{array}{c}161.1 \pm 4.62 \\
(6)\end{array}$ & $\begin{array}{c}5.01 \pm 0.62 \\
(6)\end{array}$ & $2.05 \pm 0.10$ & $\begin{array}{c}8.97 \pm 0.11 \\
(5)\end{array}$ & $\begin{array}{c}24.6 \pm 10.38 \\
(2)\end{array}$ & \\
\hline 1.5 & $\begin{array}{c}9.5 \pm 0.33 \\
(5)\end{array}$ & $\begin{array}{c}14.16 \pm 0.49 * \\
(5)\end{array}$ & $\begin{array}{c}114.2 \pm 3.10^{\prime} \\
(5) \\
\end{array}$ & $\begin{array}{r}7.71^{\prime \prime} \\
(1) \\
\end{array}$ & $\begin{array}{r}5.52^{\prime \prime} \\
(1) \\
\end{array}$ & $\begin{array}{r}14.83^{\prime \prime} \\
(1) \\
\end{array}$ & $\begin{array}{r}197.5^{\prime \prime} \\
(1) \\
\end{array}$ & 12 \\
\hline \multicolumn{9}{|c|}{ Experiment VI } \\
\hline $\begin{array}{c}0 \\
\text { (Control) }\end{array}$ & $\begin{array}{c}7.9 \pm 0.16 \\
(5)\end{array}$ & $\begin{array}{c}4.36 \pm 0.19 \\
(5)\end{array}$ & $\begin{array}{c}169.3 \pm 2.59 \\
(5)\end{array}$ & $\begin{array}{c}8.24 \pm 0.95 \\
(5)\end{array}$ & & & & \\
\hline 1 & $\begin{array}{c}7.9 \pm 0.12 \\
(10)\end{array}$ & $\begin{array}{c}4.92 \pm 0.13^{*} \\
(10)\end{array}$ & $\begin{array}{c}150.3 \pm 1.12^{\prime} \\
(10)\end{array}$ & $\begin{array}{c}5.25 \pm 0.32^{\prime} \\
(10)\end{array}$ & & & & 13 \\
\hline 7 & $\begin{array}{c}8.3 \pm 0.54 \\
\text { (3) }\end{array}$ & $\begin{array}{c}4.27 \pm 0.05 \\
(2)\end{array}$ & $\begin{array}{c}111.7 \pm 0.90^{\prime} \\
(2)\end{array}$ & 3.92 & & & & 14 \\
\hline 24 & $\begin{array}{c}7.5 \pm 0.15 \\
\text { (3) }\end{array}$ & $\begin{array}{c}3.83 \pm 0.15 \\
(3)\end{array}$ & $\begin{array}{c}86.1 \pm 2.19^{\prime} \\
(3)\end{array}$ & $\begin{array}{c}5.40 \pm 0.56 \\
(3)\end{array}$ & & & & 15 \\
\hline
\end{tabular}

* Numbers and symbols are the same as in Fig. 2,

"The serum was analyzed in a lump.

は，上茬を示し，塩分低下時には，減少が認められ，そ の傾向はクロライド舅の变動とほぼ平行している(Fig. 4)。

カリウム量：塩分上曻の場合には，(实龂 I， II）赛 験对照区の值にも差が認められ，実䮖】でま，一時的な 有意なカリウム量の減少が，認められている。この恋動 傾问が程分上㫧時に其通したすの上考完るのは困難であ る。塩分低下時の反応でも一定の傾向は得られていな い。赛験而は，急激な剌激でないために，有意差を生じ るよらな变動は想められず，実験IVの場合には上昇が実 験江の場合には隇少傾向が認められている。各奏験の対 照区の值る，大きく異なり，この成分の变動傾向は，は
つきりしない。

マグネシウム量とカルシウム量：塩分上舁時にマグネ シウム量は，害験II 22 㭙間後，整死魚がみられた时 点で上昇が認められた。その時にカルシウム量は大きな 变化はない。他方，塩分低下時には実験而で，マグネシ ウムの有意な上昇が譛められ，この実験ではカルシウム 量を上界している時期がある。これら実駼毎にみら礼る 2 洒篮の変動は实験例数が少ない故もあり，塩分变動に 伴なら変動として考えることは困難である。

コーチソール量：塩分変動がある時は，コチゾール量 が上昇することは明らかである。実験而のよらに，中る やかな条件の時以外は，龭著に高い值を示した。この成 


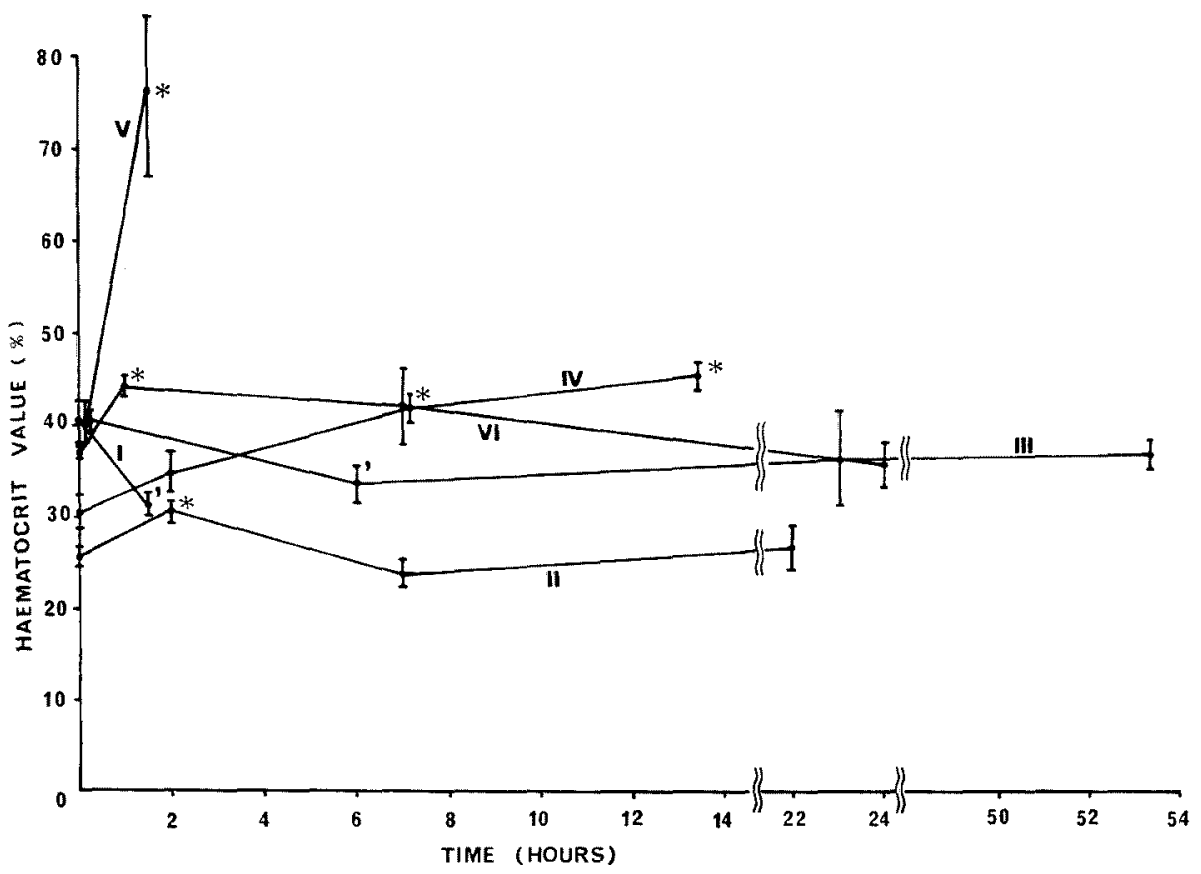

Fig. 2. Variations in haematocrit values of red sea bream under the experiments. (mean \pm S.D.)

*: significantly higher than the control level $(0 \mathrm{~h})(\alpha=0.05)$, ': significantly lower than the control level $(\alpha=0.05)$, I-VI: experiment number.

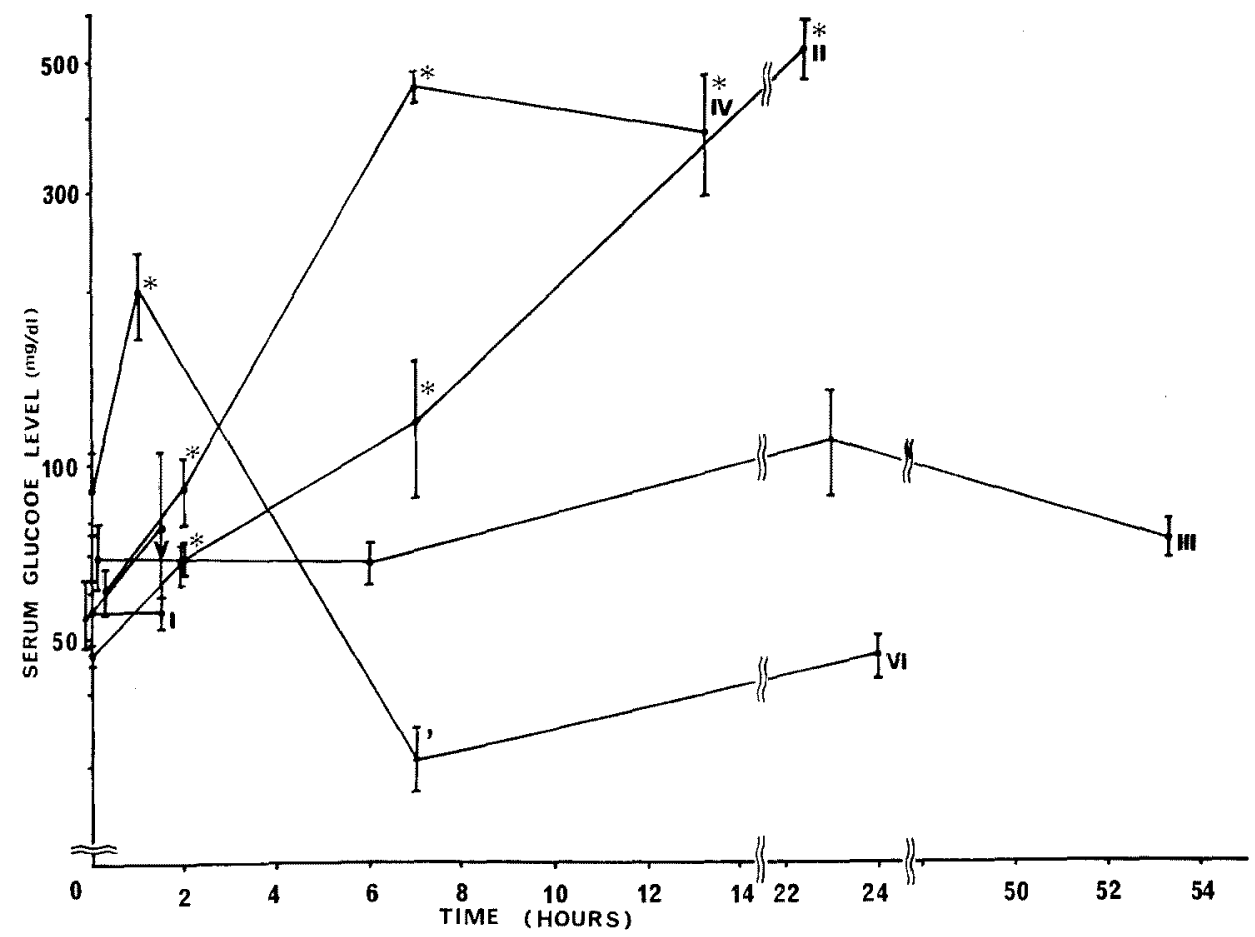

Fig. 3. Variations in serum glucose levels of red sea bream under the environmental salinity changes. (mean \pm S.D.) Numbers and symbols are the same as in Fig. 2. 


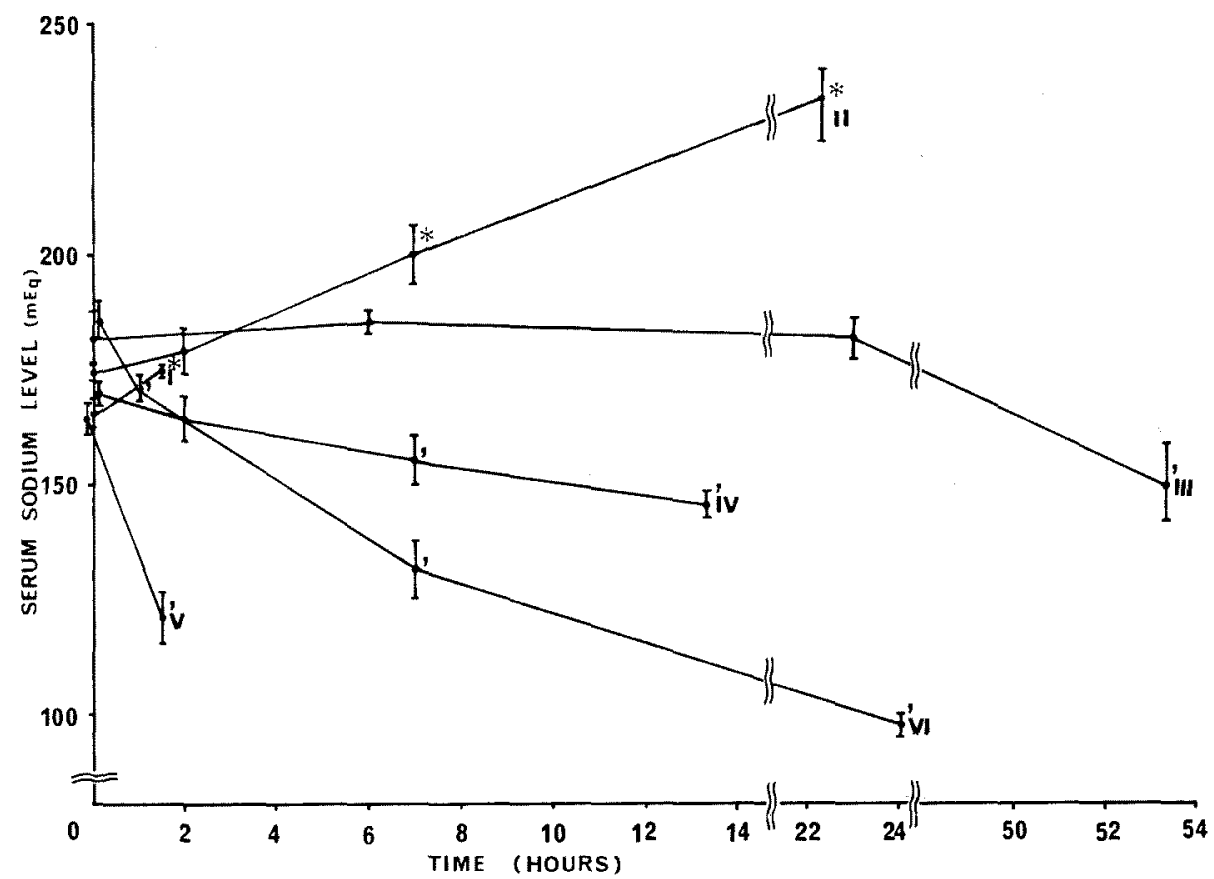

Fig. 4. Variations in serum sodium levels of red sea bream under the environmental salinity changes. (mean \pm S.D.) Numbers and symbols are the same as in Fig. 2.

分は対照区間の值の変動が大きいがその理由は明らかで ない。

\section{考察}

最近, マダイに関しては生態学的知見の集積は著しい むのがある。マダイと環境水の塩分との関倸に関しての 報告我いくつか公表されているが，塩分上昇時の知見は ほとんどみられず，塩分低下に対する反応についての諸 報告が多い。㯢山等8 ${ }^{8}$ は最初にマダイの種苗生産を試子 た時にすでに比重で $1.0220 \sim 1.0261$ の範囲であれば成 長速度には差がない上報告し，マダイの塩分耐性能の大 きいことを強調している。また, APOSTOLOPOULOS ${ }^{\text {()) }}$ マダイのふ化実験で温度と塩分の組合せの影響をみてお り, 水温 $19 \sim 25^{\circ} \mathrm{C}$, 塩分 $17 \sim 35 \%$ 筤囲ではs化率に

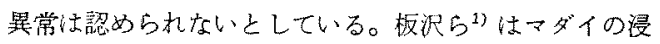
透調節に関する実馱を行い，稀积海水へ移寸之，血清浸 透代は一特的に低下寸るが，数日寸ると回復しこの経 過は，腎機能の適応的変化と深い関倸を持つとしてい 亏。

他の魚種に関して, 飼育水の高塩分化に伴なら生理学 的性状の観察は主に淡水魚中溯河性および降海性魚類で 行われており, 飼育水の低塩分化に関する研究怯海産魚 や回遊魚で研究されている。
塩分上萃時の魚の血液諸成分の反応は，金魚 ${ }^{10)},=シ 3$ マス ${ }^{11)}$, 5なぎ12 18), Channel catfish ${ }^{17)}$, Fundulus $k_{\text {kansae }}{ }^{18)}$ 等でそれぞれ異なる目的で測定されている。 示された結果は, 魚種, サンプリング時間, 条件設定な どの相違があるにもかか加らず，非常によく一致してい る。血中ナトリウム量やクロライド量は実験開始後上昇 をはじめ，やがて数日後にむとのの值かあるいはやや高 い值で安定する。コーチゾール関しては, 秒, 分, 時 間，日の単位での一過性の上暑が認められている。一マ トクリット值に関しては時間, 日の単位での上昇が認め られている。これらの反汕基本的には今回の実験にお いても認められているが，一マトクリット值の変動が穾 験条件によつて異なることや、ューチジールの初期の上 昇が認められ難かつた点等細部では相違がみられる。

塩分下降時の魚の血液成分の変動は，主に“外部環境 の变化に対応して内部環境を一定に保つ浸透圧調穊機能

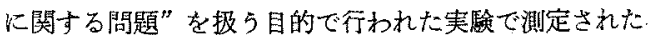
報告に多い。魚種は，らなぎ12,14,18)，海産魚のOpsanus $t^{2} u^{20)}$, Poroderma africanum ${ }^{21)}$ などで, 測定された項 目も,ナトリウム, コーチデール，へマトクリット值, 血清浸透圧等にかたよつている。これらの報告と本実驗 に共通している点は，海産魚あるい悔水に順応した淡 水魚老淡水に移した時は，血中ナトリウム量は低下する 
といら点である。初期の反応はともかく，日，週の単位 でみても，血清ナトリゥム量は低い值で安定するとして いる。最近報告の多いューチゾール関しては, 淡水に 順応したと考光られる魚では，すべてコーチゾールの上 昇俚認められていない。しかし，FAGERLUND ${ }^{22)}$ は， Sockeye salmon の河川への回㷌の過程でのコーチジー 儿値を調べ，整死状態に近らくと值は上昇するとしてい る。今回も実験亚のような場合には顕著なコーチン゙ール 上界は認められなかつたが，急激な条件の場合火性有意 な上昇が認められている。この場合の塩分変化はマダイ にとつてストレスないしは致死的ともい充る变化なのか もしれない。へマトクリット值に関しては日の単位で低 下するといら報告と変化がないといら報告がみられるの みでこれを今回の初期の反応との比較を行らことは困
難である。へマトクリット值上异の原因は, 血球の放 出, 血液の混縮, 血球の膨潤等が 考えられるが, 実驗 IV，V，VIにみられるへマトクリット值上昇時には， 一 モダロビン量のーマトクリット值に対する比率が極端に 低下していること，実驗Vで江極端な溶血が認められた こと等から血球の膨潤によるのではないかと考克られ る。委た，このへマトクリット值の上昇恃，血清ナトリ ウム量の低下やコーチゾールの上昇と同時に起つている 点などからも，浸透圧閔整機能が乱された時の特徵と考 えること出来上う。

本実験は，外部罢境の塩分変化によつて，どのように マダイの生理学的恒常性が乱され，どのような変化とし て把握することが出来るかといら観点で計画されたもの である。前報》)の温度変化の場合と異なり，塩分变化に

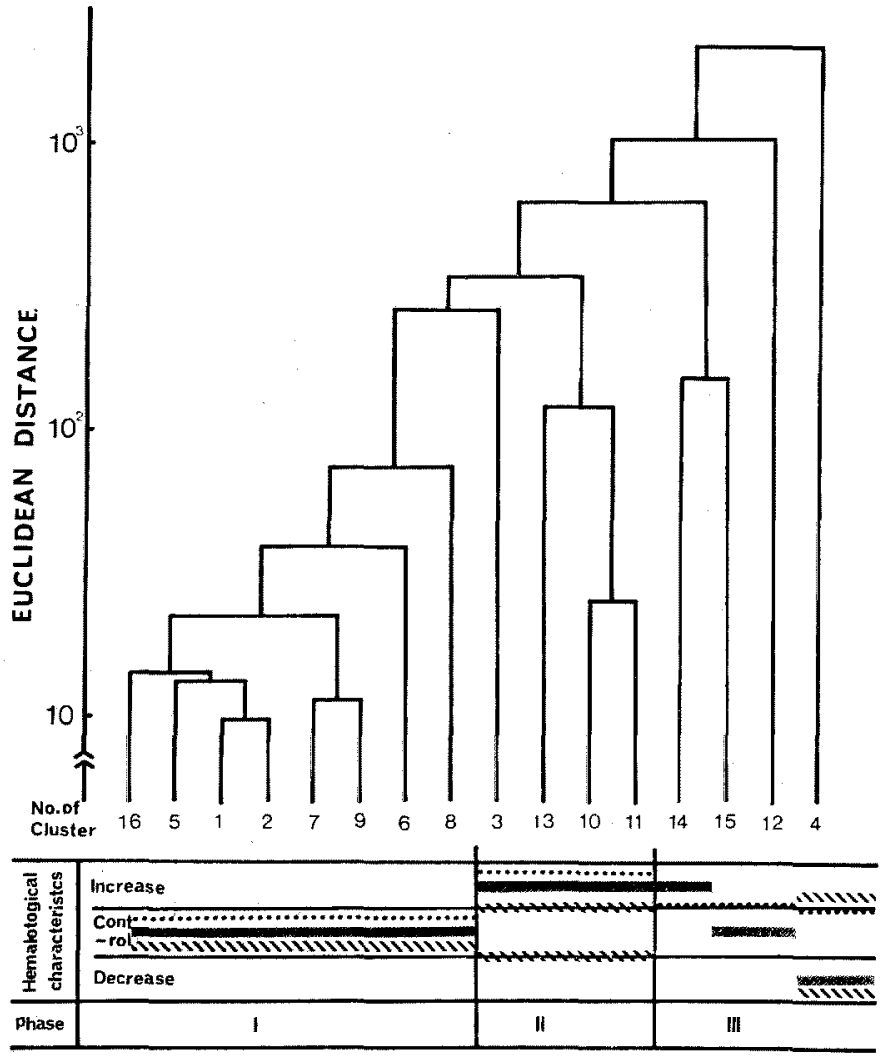

li Control phase

lli Reactive phase

Ill; Exhausitvie phase

...... Hematocrit

Glucose

INI Sodium

Fig. 5. Differentiations of haematologiocal phases on stress reactions in red sea bream under environmental salinity changes by cluster analysis. Cluster numbers are listed in Table 1 and 2. Euclidean distance $\left(d_{\alpha \beta^{2}}\right): d_{\alpha \beta^{2}}=\sum_{i=1}^{p}\left(x_{\alpha i}-x_{\beta_{i}}\right)$ 
よつて得られたマダイの血液性状変化には，特有の刺激 対応变化が強く認奶られる点が, 血中ナトリウム量, ク ロライド量の変動から明らかである。環境刺激（塩分変 化）の方向の相違にかかか子放らずに共通にみられる反応 は,グルコースとコーチゾールの変動のみであつた。ま たこの共通の反応は，刺激の絶対値そのものと同時に， その変化速度によつて引き起されるようである。

前報》で試みたように，数種類の血液性分の組及合わ せによつて魚の状態を把握するために，クラスタ一分析 を行つた。類似度は、へマトクリット值，グルコース 量,ナトリウム量の 3 变数の 3 次元空間における位置の 遠近を知るといら観点からニークリッド距離を算出する こととした。クラスターの融合は各グループの重心をと る方式に従がつた22)。変数の元データは, Tables 2, 3, Figs. 2, 4 に示した各実楺のサンプリング時間每の平均 值を整数化し，グルコースは対数変換した值を用いた。 この結果を Fig. 5 に示す。このクラスター分析結果の みからダループを分類することは難かしいが，整死魚出 現状況や，前報》のクラスタ一分析時に基淮として用い ネニークリット距離やそれぞれのグループの3 変数の平 均値の特性を総合的江考㐫て大別してみると，I～IIIの グループとして考えることが出来る。Iは，対照群を含 及，3变数が大きく対照値からはずれないグループ，II は，グルコース值が有意に上昇し，外界環境水の影響 が，へマトクリット值，ナトリウム值にわずが現われ ているダループ，且は，整死魚が認奶られたダループ で，血萑の特錐は，ナトりウム值が対照値から大きくは ずれておりグルコース值も極端に高い值から低い值に まで分布しているグループである。前報りにならい，そ れぞれのグループの特徽を名付けると，コントロール 期，反応期，疲繁期之考学ることが出来る。すなわち， コントロール期には，鰓，消化管を通じて浸透压差に由 来衣る反応が起り始める初期の反応や，塩分变化速度が あまり大きくないために，浸透王調節が十分に機能して いる状態のグループが含まれている。反応期は負荷がさ らに大きくなり，負荷を中和する機能を持つ組織器官人 速がエネルギー補充をしなければならないため，グル コースの血中への遊離が著しく增強された反応を示すグ ループが入り，疲嫳期には，負荷が大きすぎるために， 浸透王調節機能を失調し外界水の影響を強くうけて擎死 に至る前の状態にあるグループと考克ることが出来よ 5。

この各相の考え方，拉よび血液性状の在り方は，温度 变化をストレッサーとした場合と基本的には同一であ る。但し，ストレッサーが直接的に浸透圧变化を起する のであるため，表われる血液性状は号の特有の刺激（浸 透生変化)に対する反応が強調されたものとなつている。
この研究をまとめるにあたり衙校閱をいただいた東京 水産大学尾崎久雄教授と, 御鞭撻をいただいた京都大学 池田静徳教授汇深謝いたします。

\section{要約}

海産魚のストレス反応を明らかにするために，ストレ ッサーとして塩分变化刺激を与えた時のマダイの血液成 分の変動を調べた。

急激な塩分上昇刺激に対して，高血糖，血中ューチッ 一ル，ナトリウム，クロライドの上昇が認められ，急激 な塩分低下刺游に対しては，高血糖，コーチゾール上 舁，高へマトクリット值，血中ナトリウム，クロライド の低下が認められた。

これら血液性状の変動の在り方から，海産魚のストレ ス状態の分類を試み，コントロール相，反応相，疲整相 とした。反応相ではグルュース上界が䫓著で疲弊相で は,ナトリゥム量が周囲㻴境水に大きく影響を受けてい る状態が示された。

\section{文献}

1）板沢埥男・早川 悟：九大農学芸誌，26，197202 (1972).

2) K. JozuKa: Annotationes Zoologicae Japonenses, 39, 202-210 (1966).

3) M. OGuri: Bull. Japan. Soc. Sci. Fish., 26, 981-984 (1960).

4) 神谷美江: 化学々生物, 13，155-157 (1975).

5) W.T.W. PotTs, M.A. Foster, P.P. Rudy, and G.P. Howells: J. Exp. Biol., 47, 461470 (1967).

6) 内田清一郎：現代動物学の課題（日本動物学会 絀)，2, 東京大学出版会, 東京, $1974, \mathrm{pp} .53$ 82.

7) 石岡䆖子：日水誌，46, 523-531 (1980).

8) 根山英二: 陲物学䧴誌， 40, 521-522 (1928).

9) J.S. Apostolopoulos: La Mer, 4, 23-30 (1976)

10）小栗幹夫・大島 洋次郎：日 水誌，43，12531258 (1977).

11) 粟倉辉彦：魚々卵，15, 8-13 (1964).

12) J. N. Ball, I. C. Jonnes, M.E. Forster, G.H. HaRGreaves, E.F. HaEkINS, and K.P. MILNE: J. Endocr., 50, 75-96 (1971).

13) J. N. Forrest, Jr., W.C. Mackay, B. GALLAGHER, and F.H. EPSTEIN: American Journal of Physiology, 224, 714-717 (1973).

14) D.K.O. Chan, I.C. Jones, I.W. Henderson and J.C. RANKIN: J. Endocrin., 37, 297-317 (1967).

15) M. Olde and S. Utida: Marine Biol., 1, 102-106 (1967).

16) T. HiRANo and S. UtidA: Endocrinol. Japon., 18, 47-52 (1971). 
17) K.B. Davis and B.A. Simco: J. Fish. Res. Board Can., 33, 741-746 (1976).

18) J.G. Stanley and W.R. Fleming: American Zoologist, 5, 688 (1965).

19) T. HiRano: Endocrinol. Japon., 16, 557-560 (1969).
20) H. Nishimura, W. H. SAWYer, and R.F. Nigrelli: J. Endocr., 70, 47-59 (1976).

21) G. P. Haywood: Marine Biol., 29, 267-276 (1975).

22) U. H. M. Fagerlund: General and Comparative Endocrinology, 8, 197-207 (1967). 